\title{
Suspended solids induced increasing microbial ammonium recycling along the river-estuary continuum of Yangtze River
}

\author{
Jingya Xue ${ }^{1}$, Zhonghua Zhao ${ }^{1}$, Xiaolong Yao ${ }^{1}$, Weiting $\mathrm{Liu}^{1}$, and Lu Zhang ${ }^{1}$ \\ ${ }^{1}$ Chinese Academy of Sciences
}

March 23, 2021

\begin{abstract}
Many large rivers worldwide are enriched with high levels of suspended solids (SS), which are known to be hotspots of many nitrogen $(\mathrm{N})$ transformation processes (e.g., denitrification, nitrification). However, the influence of SS on microbial ammonium $(\mathrm{NH} 4+)$ recycling remains unclear. Water column NH4+ regeneration rates (REGs) and potential uptake rates (Upots) as well as community biological NH4+ demand (CBAD) was measured in the river-estuary continuum of the third longest river in the world-Yangtze River, where shows dramatic SS gradients. We found that, REGs, Upots, and CBAD all showed increasing trends along the river flow, with higher REGs, Upots, and CBAD in the estuary than in the river sections. The regeneration and uptake of $\mathrm{NH} 4+$ were nearly balanced in the river sections, while the positive CBAD in the estuary indicated obvious $\mathrm{NH} 4+$ demand of microbes. Concentrations of SS, which also controls the content of chemical oxygen demand and particulate $\mathrm{N}$, were the main factor influencing $\mathrm{NH} 4+$ recycling rates and CBAD. SS induced regenerated NH4+ in the river-estuary continuum of Yangtze River was estimated to be $21.81 \times 108 \mathrm{~kg} \mathrm{~N} \mathrm{yr}-1$ and accounted for about $25 \%$ of total N inputs, suggesting that regenerated $\mathrm{NH} 4+$ is an important $\mathrm{N}$ source for microbes and may influence nutrient dynamics in lower coasts. To our knowledge, this is the first to report NH4+ recycling in Yangtze River with an emphasis on its influencing factors and contribution to $\mathrm{N}$ budgets.
\end{abstract}

\section{Suspended solids induced increasing microbial ammonium recycling along the river-estuary continuum of Yangtze River}

Jingya Xue ${ }^{\mathrm{a}, \mathrm{b}}$, Zhonghua Zhao ${ }^{\mathrm{a}}$, Xiaolong Yao ${ }^{\mathrm{a}}$, Weiting Liu ${ }^{\mathrm{a}, \mathrm{b}}$, Lu Zhang ${ }^{\mathrm{a}} 11$ Corresponding author. Tel.: +86 2586882237; fax: +86 2557714759 E-mail:luzhang@niglas.ac.cn (L. Zhang)

a State Key Laboratory of Lake Science and Environment, Nanjing Institute of Geography and Limnology, Chinese Academy of Sciences, Nanjing 210008, China

${ }^{\mathrm{b}}$ University of Chinese Academy of Science, Beijing 100049, China

Abstract: Many large rivers worldwide are enriched with high levels of suspended solids (SS), which are known to be hotspots of many nitrogen $(\mathrm{N})$ transformation processes (e.g., denitrification, nitrification). However, the influence of SS on microbial ammonium $\left(\mathrm{NH}_{4}{ }^{+}\right)$recycling remains unclear. Water column $\mathrm{NH}_{4}{ }^{+}$regeneration rates (REGs) and potential uptake rates $\left(\mathrm{U}_{\text {pot }} \mathrm{s}\right)$ as well as community biological $\mathrm{NH}_{4}{ }^{+}$ demand $(\mathrm{CBAD})$ was measured in the river-estuary continuum of the third longest river in the worldYangtze River, where shows dramatic SS gradients. We found that, REGs, $\mathrm{U}_{\text {pot }} \mathrm{s}$, and CBAD all showed increasing trends along the river flow, with higher REGs, $\mathrm{U}_{\text {pot }} \mathrm{s}$, and CBAD in the estuary than in the river sections. The regeneration and uptake of $\mathrm{NH}_{4}{ }^{+}$were nearly balanced in the river sections, while the positive CBAD in the estuary indicated obvious $\mathrm{NH}_{4}{ }^{+}$demand of microbes. Concentrations of SS, which also controls the content of chemical oxygen demand and particulate $\mathrm{N}$, were the main factor influencing $\mathrm{NH}_{4}{ }^{+}$recycling rates and CBAD. SS induced regenerated $\mathrm{NH}_{4}{ }^{+}$in the river-estuary continuum of Yangtze River was estimated to be $21.81 \times 10^{8} \mathrm{~kg} \mathrm{~N} \mathrm{yr}^{-1}$ and accounted for about $25 \%$ of total $\mathrm{N}$ inputs, suggesting 
that regenerated $\mathrm{NH}_{4}{ }^{+}$is an important $\mathrm{N}$ source for microbes and may influence nutrient dynamics in lower coasts. To our knowledge, this is the first to report $\mathrm{NH}_{4}{ }^{+}$recycling in Yangtze River with an emphasis on its influencing factors and contribution to $\mathrm{N}$ budgets.

Keywords: Suspended solids; Ammonium recycling; River-estuary continuum; Community biological ammonium demand

\section{Introduction}

Nitrogen $(\mathrm{N})$ is an essential nutrient for organisms and the excessive inputs of $\mathrm{N}$ have led to serious eutrophication and frequent harmful algal blooms in aquatic systems (Diaz and Rosenberg, 2008; Di et al. , 2015). As an important reduced form of $\mathrm{N}, \mathrm{NH}_{4}{ }^{+}$needs the least energy for the uptake of phytoplankton and bacteria, and thus commonly shows low water column concentrations when the primary production is high (Gardneret al. , 2004; Paerl et al. , 2011). Despite within the conditions of low ambient $\mathrm{NH}_{4}{ }^{+}$concentrations and/or net fluxes (i.e., differences between the regeneration and uptake of $\mathrm{NH}_{4}{ }^{+}$), evidence have shown that raid $\mathrm{NH}_{4}{ }^{+}$recycling provides hidden $\mathrm{N}$ source for algal species (Bruesewitzet al. , 2015; Jiang et al. , 2019; Gardner et al. , 2017). Therefore, to comprehensively understand the sources and sinks of $\mathrm{N}$ and serve eutrophication control, it is crucial to evaluate $\mathrm{NH}_{4}{ }^{+}$recycling and its contribution to the ecosystem.

Water column $\mathrm{NH}_{4}{ }^{+}$recycling involves the intensively coupling of $\mathrm{NH}_{4}{ }^{+}$regeneration and uptake. The regeneration of $\mathrm{NH}_{4}{ }^{+}$is primarily contributed by the bacterial ammonification of labile organic $\mathrm{N}$ and metabolic release of zooplankton (Gardner et al. , 2004), and the uptake of $\mathrm{NH}_{4}{ }^{+}$mainly include planktonic (i.e., algae and heterotrophic bacteria) assimilation and bacterial nitrification (Hampel et al. , 2017). The balance between $\mathrm{NH}_{4}{ }^{+}$regeneration and uptake can be reflected by calculating community biological $\mathrm{NH}_{4}{ }^{+}$ demand (CBAD), which indicates net microbial community demand for $\mathrm{NH}_{4}{ }^{+}$(Gardner et al. , 2017).

Recycling rates of $\mathrm{NH}_{4}{ }^{+}$and the CBAD varied among different water bodies under the influence of various environmental factors and ecosystem characteristics. Nutrient concentrations, organic matter, and chlorophyll $a$ (Chl- $a$ ) are common factors influencing $\mathrm{NH}_{4}{ }^{+}$recycling rates in eutrophic lakes, estuaries, and coasts (Bruesewitzet al. , 2015; Gudasz et al. , 2015; Jiang et al. , 2019). In high turbid rivers, besides the factors mentioned above, suspended solid (SS) is also an important factor influencing $\mathrm{NH}_{4}{ }^{+}$recycling processes (Xue et al. , 2019). SS supports the metabolism of attached heterotrophic bacteria (i.e., nitrification, denitrification, and nitrous oxide emission) by providing ideal oxic or anoxic interfaces with easily available substrates from SS or its surrounding water (Xia et al. , 2009; Liu et al. , 2013; Yao et al. , 2016; Zhouet al. , 2019; Zheng et al. , 2017). However, the influence of SS on microbial $\mathrm{NH}_{4}{ }^{+}$recycling remains unclear.

Characterized by low retention time, drastic flushing effects, and dramatic SS changes, river-estuary continuums exhibit typical gradients of nutrient concentrations and dynamics (Mccarthy et al. , 2007b; Bruesewitzet al. , 2015; Liang and Xian, 2018). Previous studies in river-estuary continuums usually focused on N loads and its exports (Liang and Xian, 2018), long-term changes of nutrient concentrations (Liu et al. , 2018), and responses of phytoplankton community to increased nutrients input (Zhou et al. , 2008). Relatively fewer studies are focused on $\mathrm{NH}_{4}{ }^{+}$recycling in river-estuary continuums and its effect factors. $\mathrm{NH}_{4}{ }^{+}$recycling in river-estuary continuums may not support severe algal blooms as in eutrophic lakes, while it is still playing an important role in microbial growth and can impact nutrient dynamics in the systems and even lower coasts.

In recent decades, algal blooms increased dramatically in the estuary of Yangtze River in terms of frequency, area, and persistence time (Zhouet al. , 2008; Tang et al. , 2006; Dai et al. , 2011; Jiang et al. , 2014). It has been known that external $\mathrm{N}$ inputs play an important role in supporting algal blooms in the estuary of Yangtze River (Zhou et al. , 2008), while the contribution of water column N recycling is unclear. We hypothesized that $\mathrm{NH}_{4}{ }^{+}$recycling would provide enormous $\mathrm{N}$ for microbes in the river-estuary continuum of Yangtze River, and the volume of regenerated $\mathrm{NH}_{4}{ }^{+}$have the potential to support algal blooms in the estuary. The aims of this study are to: (1) quantify $\mathrm{NH}_{4}{ }^{+}$uptake and regeneration rates as well as CBAD; 
(2) examine the effects of SS and other environmental factors on $\mathrm{NH}_{4}+$ recycling rates; (3) evaluate the contribution of regenerated $\mathrm{NH}_{4}{ }^{+}$to $\mathrm{N}$ budgets and explore implications. This study is the first to report $\mathrm{NH}_{4}{ }^{+}$recycling and CBAD in the river-estuary continuum of Yangtze River. The results of our study provide a basis for the comprehensive understanding of $\mathrm{N}$ sources in the Yangtze River and the formulation of $\mathrm{N}$ management strategies.

\section{Methods}

\subsection{Study area and sampling sites}

The Yangtze River (also called Changjiang River), originating from the Qinghai-Tibet Plateau, is the third longest river in the world, with a total mainstream length of about $6300 \mathrm{~km}$, a basin area of $1.8 \times 10^{6} \mathrm{~km}^{2}$ and an average annual discharge of $892 \mathrm{~km}^{3}$ (Yan et al. , 2010)(Fig. 1). In China, the river is divided based on watershed boundaries into three reaches, the upper reaches (upstream of Yichang), middle reaches (between Yichang and Hukou) and lower reaches (downstream of Hukou) (Wang et al. , 2008). The lower reaches areas of Yangtze River have dense river networks, numerous lakes, extensive plains and dense cities, forming a prosperous industrial belt, but also facing ecological environment problems such as the increasing concentrations of nutrient in the watershed, frequent occurrence of harmful algal blooms in lakes and severe red tide in estuaries (Yi et al. , 2011; Qinet al. , 2010; Tang et al. ,2006; Liu et al. , 2018). In addition, the lower reaches of Yangtze River can be subdivided into three parts, the Anhui section, Jiangsu section and estuary, according to the provinces and tidal (Fig. 1) .

In this study, 44 surface water samples ( $0.5 \mathrm{~m}$ below the water surface) were collected from the river-estuary continuum of the Yangtze River coastal zone in July, 2018, to investigate the spatial changes of REGs and $\mathrm{U}_{\text {pot }} \mathrm{S}$ (Fig. 1). There were 19 (CJ1 CJ19), 15 (CJ20 CJ34) and 10 (CJ35 CJ44) sites belonging to the Anhui section, Jiangsu section and estuary, respectively.

\subsection{Sample collection and analysis}

Surface water for $\mathrm{NH}_{4}{ }^{+}$recycling experiments were collected in $1 \mathrm{~L}$ carboys. Water samples for nutrient concentrations $\left(\mathrm{NO}_{3}^{-}, \mathrm{NO}_{2}^{-}\right.$, and $\mathrm{NH}_{4}{ }^{+}$) analyses were filtered through $0.7 \mu \mathrm{m}$ fiberglass filters (Whatman $\mathrm{GF} / \mathrm{F}$ ) immediately following collection in the field. Water temperature, dissolved oxygen (DO), and $\mathrm{pH}$ were measured in situ using a multi-parameter water quality analyzer (YSI Professional Plus, 6600V2, USA). All samples were collected in triplicate and were immediately stored in a dark cooler. Total dissolved nitrogen (TDN), total dissolved phosphorus (TDP), ammonium $\left(\mathrm{NH}_{4}{ }^{+}\right)$, nitrate $\left(\mathrm{NO}_{3}{ }^{-}\right)$, nitrite $\left(\mathrm{NO}_{2}{ }^{-}\right)$, and phosphate $\left(\mathrm{PO}_{4}{ }^{3-}\right)$ concentrations were analyzed in filtered samples (Jin and $\left.\mathrm{Tu}, 1990\right)$. Concentrations of TDN and TDP were determined using the potassium persulfate digestion and spectrophotometric method (detection limits of $4 \mu \mathrm{mol} \mathrm{N} \mathrm{L}-1$ and $1 \mu \mathrm{mol} \mathrm{P} \mathrm{L}{ }^{-1}$ for TDN and TDP, respectively). $\mathrm{NH}_{4}{ }^{+}$was determined using the nesslerization colorimetric method (detection limit $1 \mu \mathrm{mol} \mathrm{N} \mathrm{L}{ }^{-1}$ ). $\mathrm{NO}_{3}{ }^{-}$and $\mathrm{NO}_{2}{ }^{-}$were determined using the phenol acid ultraviolet colorimetric method (detection limit $3 \mu \mathrm{mol} \mathrm{N} \mathrm{L} \mathrm{N}^{-1}$ ) and N-(1-naphthyl)ethylenediamine colorimetric method (detection limit $0.2 \mu \mathrm{mol} \mathrm{N} \mathrm{L} \mathrm{N}^{-1}$ ), respectively. Total nitrogen (TN) and total phosphorus (TP) were determined on unfiltered water samples using the potassium persulfate digestion and spectrophotometric method (Jin and Tu, 1990). Particulate nitrogen (PN) was calculated as the difference between TN and TDN, and the standard deviation for PN was obtained using a propagation of error analysis. $\mathrm{NO}_{\mathrm{x}}{ }^{-}$was the sum of $\mathrm{NO}_{3}{ }^{-}$and $\mathrm{NO}_{2}{ }^{-}$. Urea was measured using diacetylmonoxime reagent, and the detection limit was $0.04 \mu \mathrm{mol}$ Urea- $\mathrm{N} \mathrm{L}^{-1}$ (Mulvenna and Graham, 1992). Chl-aconcentrations, chemical oxygen demand (COD), and suspended solid (SS) were determined using standard methods (Jin and Tu, 1990). Dissolved organic carbon (DOC) concentrations were determined using TOC-V CPN (Shimadzu, Tokyo, Japan) analyzer at high temperature $\left(680{ }^{\circ} \mathrm{C}\right)$ after being acidified with $10 \mu \mathrm{L}$ of $85 \% \mathrm{H}_{3} \mathrm{PO}_{4}$. 


\section{$2.3 \mathrm{NH}_{4}{ }^{+}$regeneration and uptake experiment}

Water column REGs and $\mathrm{U}_{\text {pot }} \mathrm{s}$ were determined using isotope dilution methods. Isotope dilution experiments are usually conducted with low trace amendment level (about 10\% of ambient) (Glibert et al. , 1982). However, low $\mathrm{NH}_{4}{ }^{+}$concentrations and fast $\mathrm{NH}_{4}{ }^{+}$recycling rates in summer flood season of Yangtze River may lead to depleted $\mathrm{NH}_{4}{ }^{+}$pool before the end of incubation (Blackburn, 1979), excess ${ }^{15} \mathrm{NH}_{4}{ }^{+}$(approximately $20 \mu \mathrm{mol} \mathrm{N} \mathrm{L}{ }^{-1}$ ), as the reaction product rather than as a potentially limiting substrate, was added at the beginning of incubation (Mccarthy et al. , 2007a). Excessive ${ }^{15} \mathrm{NH}_{4}{ }^{+}$addition can promote $\mathrm{NH}_{4}{ }^{+}$uptake rates, so the $\mathrm{NH}_{4}{ }^{+}$uptakes obtained in this study were potential rates. On the other hand, because $\mathrm{NH}_{4}{ }^{+}$ is the end product rather than the substrate, excess additions will not affect regeneration rates (Blackburn, 1979).

Water from each site was enriched with $98 \%{ }^{15} \mathrm{NH}_{4} \mathrm{Cl}$ and decanted into duplicate clear polystyrene culture bottles (70 ml; Coring) after thoroughly mixed. Initial samples were filtered through a rinsed $0.2 \mu \mathrm{m}$ syringe filter immediately after enrichment and mixing for total $\mathrm{NH}_{4}{ }^{+}$concentrations and $\mathrm{NH}_{4}{ }^{+}{ }^{15} \mathrm{~N}$ analysis. Bottles were incubated in a transparent bucket containing Yangtze River water to provide near-ambient light and temperature for $24 \mathrm{~h}$. After incubation, final samples were collected in the same way as the initial samples. $\mathrm{NH}_{4}{ }^{+}{ }^{15} \mathrm{~N}$ was measured using $\mathrm{NH}_{4}{ }^{+}$oxidation membrane inlet mass spectrometry (OX/MIMS) (Yin et al. , 2014).

Water column REGs and $\mathrm{U}_{\mathrm{pot}} \mathrm{s}$ were calculated using a modified isotope dilution method (Glibert et al. , 1982; Blackburn, 1979). The relative abundance of $\mathrm{NH}_{4}+{ }^{+}{ }^{15} \mathrm{~N}(R)$ is required to calculate the REGs and $\mathrm{U}_{\mathrm{pot}} \mathrm{s}$, which can be calculated as:

$$
R={ }^{15} N /\left({ }^{15} N+{ }^{14} N\right)
$$

where ${ }^{15} \mathrm{~N}$ and ${ }^{14} \mathrm{~N}$ are the concentrations of $\mathrm{NH}_{4}{ }^{+}{ }^{15} \mathrm{~N}_{\text {and }} \mathrm{NH}_{4}{ }^{+}{ }^{14} \mathrm{~N}\left(\mu \mathrm{mol} \mathrm{N} \mathrm{L}{ }^{-1}\right)$, respectively.

The REGs can be calculated as follows (Bruesewitz et al. , 2015), which was derived from the logarithmic equations of Blackburn (1979):

$$
\mathrm{REG}=\left(R_{0}-R_{t}\right) / t \times\left(C_{0} / R_{t}\right)
$$

where $R_{0}$ and $R_{t}$ are the relative abundances of $\mathrm{NH}_{4}{ }^{+}{ }^{15} \mathrm{~N}$ at the initial and finial point, respectively, and $t$ is the incubation time (h). $C_{0}$ is the initial concentrations of $\mathrm{NH}_{4}^{+}\left(\mu \mathrm{mol} \mathrm{N} \mathrm{L}{ }^{-1}\right)$. REGs $\left(\mu \mathrm{mol} \mathrm{N} \mathrm{L}^{-1} \mathrm{~h}^{-1}\right)$ are absolutely positive values, indicating the actual regeneration rates of $\mathrm{NH}_{4}{ }^{+}$.

The $\mathrm{U}_{\text {pot }} \mathrm{s}\left(\mu \mathrm{mol} \mathrm{N} \mathrm{L} \mathrm{N}^{-1} \mathrm{~h}^{-1}\right)$ were calculated with the $\mathrm{NH}_{4}{ }^{+}$concentrations change and regeneration rates (Bruesewitz et al. , 2015):

$$
U_{\mathrm{pot}}=\left(C_{t}-C_{0}-R E G \times t\right) / t
$$

where $C_{0}$ and $C_{t}$ are the initial and finial concentrations of $\mathrm{NH}_{4}+(\mu \mathrm{mol} \mathrm{N} \mathrm{L}-1)$.

CBAD characterizes internal $\mathrm{NH}_{4}{ }^{+}$recycling by representing the difference between measured potential $\mathrm{NH}_{4}{ }^{+}$ uptake rates and actual $\mathrm{NH}_{4}+$ regeneration rates in aquatic systems (Gardner et al. , 2017). Therefore, CBAD was calculated as:

$$
\mathrm{CBAD}=U_{\text {pot }}-R E G
$$




\subsection{Statistical analysis}

Statistical analyses were performed using SPSS 22.0. One-way analysis of variance (one-way ANOVA) combined with the Independent-Samples T-test were used to evaluate statistically significant differences between group average values. Pearson correlation analyses were applied to analyze the relationship between $\mathrm{NH}_{4}{ }^{+}$recycling rates and environmental factors. Differences and correlations were considered statistically significant at $p<0.05$.

\section{Results}

\subsection{Water column physicochemical characteristics}

The physicochemical characteristics of water column in the Yangtze River are shown in Table 1 . Water temperature in Anhui section, Jiangsu section and estuary ranged from 27.4 to 30.1, 27.6 to 30.2 and 28.6 to 30.0, respectively, and was significantly higher in estuary than in Anhui and Jiangsu section $(p<0.05)$. Chl- $a$ concentrations were significantly higher in estuary than in river (Anhui and Jiangsu) sections $(p<$ 0.05). COD concentrations were highest in estuary $(6.14 \pm 1.74 \mathrm{mg} / \mathrm{L})$ and lowest in Anhui section (4.05 $\pm 0.75 \mathrm{mg} / \mathrm{L})(p<0.05)$. Similar to the distribution of COD, DOC concentrations were highest in estuary $(14.5 \pm 5.3 \mathrm{mg} / \mathrm{L})$ and lowest in Anhui section $(6.6 \pm 4.0 \mathrm{mg} / \mathrm{L})(p<0.05)$. SS concentrations ranged from 7 to $1315 \mathrm{mg} / \mathrm{L}$, and the highest values were observed in estuary.

In all sites, $\mathrm{N}$ concentrations, including TN, $\mathrm{PN}, \mathrm{NH}_{4}{ }^{+}, \mathrm{NO}_{\mathrm{x}}{ }^{-}$and urea, ranged from 131 to 307,1 to $158,<$ 1.0 to $13.0,41$ to $214,<0.04$ to $19.7 \mu \mathrm{mol} \mathrm{N} \mathrm{L}{ }^{-1}$ with average values of $196 \pm 38,56 \pm 43,4.5 \pm 2.8,112 \pm$ $34,5.5 \pm 5.7 \mu \mathrm{mol} \mathrm{N} \mathrm{L}{ }^{-1}$, respectively (Table 1 ). Along the river-estuary continuum, $\mathrm{TN}, \mathrm{PN}$, and $\mathrm{NH}_{4}{ }^{+}$ showed similar increasing trends with the direction flow, while no significant trends were observed in $\mathrm{NO}_{\mathrm{x}}{ }^{-}$ concentrations. TP concentrations ranged from 0.32 to $7.03 \mu \mathrm{mol} \mathrm{P} \mathrm{L} \mathrm{P}^{-1}$, with the highest values in Anhui section $\left(3.35 \pm 1.39 \mu \mathrm{mol} \mathrm{P} \mathrm{L}{ }^{-1}\right)$ and lowest in Jiangsu section $\left(1.69 \pm 1.23 \mu \mathrm{mol} \mathrm{P} \mathrm{L}{ }^{-1}\right)(p<0.05)$.

\section{$3.2 \mathrm{NH}_{4}{ }^{+}$regeneration and potential uptake rates}

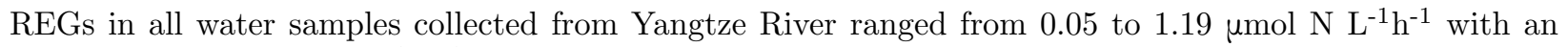
average of $0.26 \mu \mathrm{mol} \mathrm{N} \mathrm{L} \mathrm{N}^{-1} \mathrm{~h}^{-1}$, showing an increased trend along the river-estuary continuum(Fig. 2) . The REGs were significantly lower in Anhui section $\left(0.14 \pm 0.09 \mu \mathrm{mol} \mathrm{N} \mathrm{L}{ }^{-1} \mathrm{~h}^{-1}\right)$ than in Jiangsu section $\left(0.31 \pm 0.18 \mu \mathrm{mol} \mathrm{N} \mathrm{L} \mathrm{N}^{-1} \mathrm{~h}^{-1}\right)$ and estuary $\left(0.44 \pm 0.33 \mu \mathrm{mol} \mathrm{N} \mathrm{L} \mathrm{L}^{-1} \mathrm{~h}^{-1}\right)(p<0.05)$. $\mathrm{U}_{\text {pot }} \mathrm{S}$ in the river-

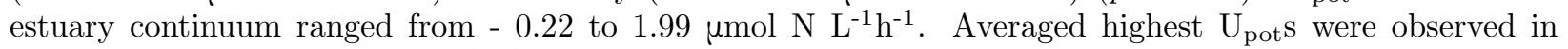
estuary $\left(0.73 \pm 0.56 \mu \mathrm{mol} \mathrm{N} \mathrm{L}{ }^{-1} \mathrm{~h}^{-1}\right)$, which were about 2 and 5 times higher than that in Jiangsu $(0.32 \pm$ $\left.0.21 \mu \mathrm{mol} \mathrm{N} \mathrm{L} \mathrm{N}^{-1} \mathrm{~h}^{-1}\right)$ and Anhui section $\left(0.15 \pm 0.14 \mu \mathrm{mol} \mathrm{N} \mathrm{L}-1 \mathrm{~h}^{-1}\right)(p<0.05)$, respectively. Similar to the spatial characteristics of REGs, $\mathrm{U}_{\text {pot }} \mathrm{s}$ also increased along the river-estuary continuum (Fig. 3), and there was a positive correlation between REGs and $\mathrm{U}_{\text {pot }} \mathrm{S}(\mathrm{r}=0.89, p<0.01)$ (Fig. S1) . In addition, the REGs accounted for $62 \% \pm 18 \%$ of the $\mathrm{U}_{\text {pot }} \mathrm{S}$ during the study period, this may suggest the processes of $\mathrm{NH}_{4}{ }^{+}$recycling $\left(\mathrm{NH}_{4}{ }^{+}\right.$regeneration and uptake) are critical for regulating the supply of $\mathrm{NH}_{4}{ }^{+}$along the river-estuary continuum (Bruesewitz et al. , 2015).

\subsection{Community biological $\mathrm{NH}_{4}{ }^{+}$demand (CBAD)}

Community biological $\mathrm{NH}_{4}{ }^{+}$demand $(\mathrm{CBAD})$ relates $\mathrm{N}$ dynamics to total microbial productivity and $\mathrm{NH}_{4}{ }^{+}$ deprivation in aquatic systems (Gardner et al. , 2017), and CBAD is approximated by observing differences between the potential $\mathrm{NH}_{4}{ }^{+}$uptake rates and actual $\mathrm{NH}_{4}{ }^{+}$regeneration rates (Gardner et al. , 2017). CBAD in the samples collected from Yangtze River ranged from - 0.43 to $0.80 \mu \mathrm{mol} \mathrm{N} \mathrm{L}{ }^{-1} \mathrm{~h}^{-1}$, with the highest values found in estuary $\left(0.30 \pm 0.24 \mu \mathrm{mol} \mathrm{N} \mathrm{L} \mathrm{N}^{-1} \mathrm{~h}^{-1}\right)$ and the relatively lower values in Anhui $(0.02 \pm 0.16$ $\left.\mu \mathrm{mol} \mathrm{N} \mathrm{L}{ }^{-1} \mathrm{~h}^{-1}\right)$ and Jiangsu $\left(0.01 \pm 0.09 \mu \mathrm{mol} \mathrm{N} \mathrm{L}{ }^{-1} \mathrm{~h}^{-1}\right)$ section $(p<0.05)$ (Fig. 4) . The positive and 
negative values of $\mathrm{CBAD}$ indicate the relative magnitude of the $\mathrm{NH}_{4}{ }^{+}$potential uptake and regeneration rates. There were 6 and 8 sites in Anhui and Jiangsu sections showing negative values of CBAD, accounting for approximately $32 \%$ and $53 \%$ of the sampling sites, respectively. However, the CBAD rates of all sites in the estuary were positive values.

\section{Discussion}

\section{1 $\mathrm{NH}_{4}{ }^{+}$recycling rates and contribution to the $\mathrm{N}$ budget in Yangtze River}

REGs and $\mathrm{U}_{\text {pot }} \mathrm{s}$ from Yangtze River were $0.26\left(0.05^{\sim} 1.19\right) \mu \mathrm{mol} \mathrm{N} \mathrm{L} \mathrm{N}^{-1} \mathrm{~h}^{-1}$ and $0.34\left(-0.22^{\sim} 1.99\right) \mu \mathrm{mol} \mathrm{N}$ $\mathrm{L}^{-1} \mathrm{~h}^{-1}$, respectively. Generally, the REGs and $\mathrm{U}_{\mathrm{pot}} \mathrm{S}$ in this study were within the range of values reported elsewhere (Table 2 ). In detail, they were comparable to several major polluted inflow rivers of Lake Taihu, China (Jiang et al. , 2019), but were higher than that from the low nutrients and low primary production Old Woman River (Mccarthy et al. , 2007b), Aransas River and Mission River (Bruesewitz et al. , 2015). Compared to other eutrophic lakes, such as Lake Taihu, Lake Petit saut and Lake Maracaibo (Gardner et al. , 1998; Collos et al. , 2001; Jiang et al. , 2019), insignificantly lower REGs and $\mathrm{U}_{\text {pot }} \mathrm{s}$ were observed in the river-estuary continuum of Yangtze River. In addition, it is noteworthy that compared with lake ecosystems, river ecosystems tend to be found the greater REGs than $\mathrm{U}_{\mathrm{pot}} \mathrm{s}$, suggesting a potential release risk of $\mathrm{NH}_{4}{ }^{+}$ in the river water column.

Sources of $\mathrm{NH}_{4}{ }^{+}$to Yangtze River mainly include external nutrient inputs (river input, atmospheric deposition, and sediment release) and undocumented regenerated $\mathrm{NH}_{4}{ }^{+}$. Although it has been confirmed that the internal recycling processes play a vital important role in the $\mathrm{NH}_{4}{ }^{+}$budget and ecological effect in eutrophic lakes (Wu et al. , 2017; Paerl et al. , 2011), the contribution of regenerated $\mathrm{NH}_{4}{ }^{+}$to river-estuary continuum of Yangtze River is still unclear. Here we provide the first estimation of contribution from regenerated $\mathrm{NH}_{4}{ }^{+}$ to the $\mathrm{N}$ budget. Previous study has reported that river $\mathrm{N}$ input from the upper and middle reaches of Yangtze River was $57.14 \times 10^{8} \mathrm{~kg} \mathrm{~N} \mathrm{yr}^{-1}$, and $\mathrm{N}$ input in the lower reaches of Yangtze River (study area of this study) was estimated as $4.87 \times 10^{8} \mathrm{~kg} \mathrm{~N} \mathrm{yr}^{-1}$ (Liu et al. , 2018). Atmospheric deposition in our study area was estimated as $2.76 \times 10^{8} \mathrm{~kg} \mathrm{~N} \mathrm{yr}^{-1}$, which was calculated as the deposition to emission ratio (Chen et al. , 2016). $\mathrm{N}$ input from sediments was estimated as $2.19 \times 10^{8} \mathrm{~kg} \mathrm{~N} \mathrm{yr}^{-1}$ (estimated using the total mineralized $\mathrm{N}$ in the sediments minus the sum of denitrification, anammox and microbial $\mathrm{N}$ assimilation) (Lin et al. , 2016). Based on The Changjiang Bulletin issued by the Changjiang Water Resources Commission of the Ministry of Water Resources in 2018, the annual runoff of Datong station (Fig.1) in 2018 was 8028 x $10^{8} \mathrm{~m}^{3}$. Together with average REGs in the river-estuary continuum, we can estimate riverine regenerated $\mathrm{NH}_{4}{ }^{+}$was approximately $21.8 \times 10^{8} \mathrm{~kg} \mathrm{~N} \mathrm{yr}^{-1}$. Compared with other $\mathrm{N}$ sources in the Yangtze River (Fig. 5) , the regenerated $\mathrm{NH}_{4}{ }^{+}$is lower than riverine input from upper and middle reaches, but much higher than $\mathrm{N}$ input from lower reaches, atmospheric deposition, and sediments release. The regenerated $\mathrm{NH}_{4}{ }^{+}$accounts for $25 \%$ of total $\mathrm{N}$ inputs in the study area, suggesting that regenerated $\mathrm{NH}_{4}{ }^{+}$is an important internal $\mathrm{N}$ source for microbes and may influence nutrient dynamics in lower coasts. Although the summer rates of REGs can be significantly higher than in other seasons (Bruesewitz et al. , 2015; Jiang et al. , 2019), which made the annual regenerated $\mathrm{NH}_{4}{ }^{+}$be overestimated, this ratio is high enough and could not be neglected.

\subsection{Effects of $\mathrm{SS}$ on $\mathrm{NH}_{4}+$ recycling rates}

No significant correlation between REGs and Chl- $a$ was found in this study ( $\mathrm{r}=0.220, p>0.05$ ) (Table 3) , indicating that algae was not the major source of regenerated $\mathrm{NH}_{4}{ }^{+}$. Unlike in eutrophic lakes (e.g., Lake Taihu, Jiang et al. , 2019), algae abundance in Yangtze River was low $\left(2.8+-3.2 \mu \mathrm{g} \mathrm{L}{ }^{-1}\right)$ due to high turbidity and washout from the high velocity of water flow in the Yangtze River, which leads to low concentrations of algae-derived organic N. However, significant correlations between REGs and SS instead of between REGs and DOC $(\mathrm{r}=0.197, p>0.05)$ or DON $(\mathrm{r}=0.111, p>0.05)$ suggested that REGs were mainly influenced by allochthonous particulate matters. SS is a complex mixture of organic detritus, microorganisms, and other 
organisms (Turner and Millward, 2002; Odman et al. , 1999), and SS in Yangtze River mainly come from the input of basin and soil erosion (Yang et al. , 2007). In this study, SS were positively correlated with COD $(\mathrm{r}=0.535, p<0.01)$, and TN $(\mathrm{r}=0.304, p<0.05)$, and $\mathrm{PN}(\mathrm{r}=0.478, p<0.01)$ (Fig. S2), suggesting that SS can act as a vector of nutrient to promote $\mathrm{N}$ cycling processes (Bilotta and Brazier, 2008; Zhang et al. , 2019). Moreover, significant correlations between REGs and COD (roughly represent the content of particulate and dissolved organic matter $)(\mathrm{r}=0.608, p<0.01)$ and $\mathrm{PN}(\mathrm{r}=0.455, p<0.01)$ provide further evidence that heterotrophic bacterial (e,g., ammonifying bacteria) degradation of allochthonous particulate organic matters influences regeneration rates of $\mathrm{NH}_{4}{ }^{+}$. Ammonifying bacteria, a major participant for $\mathrm{NH}_{4}{ }^{+}$ regeneration activities, is abundant and widespread in river systems and tended to attach on SS (Xiaet al. , 2013). Ammonifying bacteria population in culture with $5 \mathrm{~g} \mathrm{~L}^{-1} \mathrm{SS}$ of river systems were shown two orders of magnitude higher than that without SS (Xia et al. , 2013). Thus, high regeneration rates of $\mathrm{NH}_{4}{ }^{+}$in Yangtze River were deduced to be mainly contributed by heterotrophic bacteria attached on high levels of SS and PN in SS provides important substrate for bacterial metabolism.

$\mathrm{NH}_{4}{ }^{+}$uptake is primarily composed of nitrification as well as assimilation by phytoplankton (Hampel et al. , 2017). However, the low biomass of phytoplankton in the turbidity river may contribute less to $\mathrm{NH}_{4}{ }^{+}$uptake. This is supported by the insignificant correlation between $\mathrm{U}_{\text {pot }} \mathrm{s}$ and Chl- $a(\mathrm{r}=0.257, p>$ 0.05). Study reported that nitrification rates increased with SS as a power function in the Yellow River, China, which was characterized by high SS concentrations (Xia et al. , 2009). Combined with high SS concentrations and low algae biomass in the Yangtze River, we can infer that $\mathrm{NH}_{4}{ }^{+}$uptake is mainly due to nitrification on SS. In this study, the SS concentrations were found to be significantly correlated with $\mathrm{U}_{\text {pot }} \mathrm{S}$ $(\mathrm{r}=0.825, p<0.01)$, which evidences the importance of SS in the $\mathrm{NH}_{4}{ }^{+}$uptake process. Other factors such as the concentrations of $\mathrm{COD}, \mathrm{TN}$ and $\mathrm{PN}$ can also affect $\mathrm{NH}_{4}{ }^{+}$uptake rates. This may be due to the significant positive correlations between COD, TN, PN and the REGs, which provides abundant substrates for the uptake of $\mathrm{NH}_{4}{ }^{+}$.

\subsection{Higher planktonic $\mathrm{NH}_{4}{ }^{+}$demand in the estuary than river section of Yangtze River}

Many studies have reported that Yangtze River estuary is characterized as P limitation due to sufficient $\mathrm{N}$ inputs (Wong et al. , 1998; Liang and Xian, 2018). However, results in this study suggest that planktonic $\mathrm{NH}_{4}{ }^{+}$limitation may also occur in the river-estuary continuum of Yangtze River. CBAD as the index of $\mathrm{NH}_{4}{ }^{+}$limitation in water, addresses the vital question whether or not the $\mathrm{NH}_{4}{ }^{+}$demand of plankton could be met by $\mathrm{NH}_{4}{ }^{+}$recycling in the water column (Jiang et al. , 2019; Gardner et al. , 2017). Our results showed that CBAD in the estuary of Yangtze River were significantly higher than in the Anhui and Jiangsu sections (near zero) (Fig. 4), where $\mathrm{NH}_{4}{ }^{+}$regeneration and uptake were nearly balanced.

Significant higher CBAD in the estuary could be due to several possible reasons. First, high concentrations of SS can not only promote microbial nitrification, but also accelerate $\mathrm{NH}_{4}{ }^{+}$regeneration (Xia et al. , 2013; Xue et al. , 2019). Our results further indicated that SS concentrations promoted $\mathrm{U}_{\text {pot }} \mathrm{S}$ faster than REGs (Fig.6 ), resulting in higher CBAD in the estuary of Yangtze River. Second, higher water temperatures (averaged $29.2 \pm 0.5$ ) in the estuary than other sections (averaged 28.4 +- 0.7 in Jiangsu section, averaged $28.1+-0.8$ in Anhui section) of Yangtze River promote the higher CBAD values and $\mathrm{NH}_{4}{ }^{+}$limitation. Culture incubations in Lake Taihu showed that $\mathrm{U}_{\mathrm{pot}} \mathrm{s}$ increased faster than REGs in response to increasing water temperature between 5.0 and 32.9 (Jiang et al. , 2019). Another possible explanation for the higher CBAD in estuary is the higher plankton biomass. Previous studies reported that approximately $57 \%$ of bacterial cells were retained on the $0.7 \mu \mathrm{m}$ filters and confirmed the presence of small phytoplankton and archaea through DNA analysis (Sipler et al. , 2017; Connelly et al. ,2014). Our results showed that PN was significantly correlated with Chl- $a(\mathrm{r}=0.314, p<0.05)$ (Fig. S3). Thus, PN concentrations can approximately represent biomass $\mathrm{N}$ of plankton intercepted by filters $(\mathrm{GF} / \mathrm{F})$. Comparing with the river sections, the estuary showed higher PN concentrations and CBAD increased with increasing PN concentrations $(\mathrm{r}=0.44, p<0.01)$, implying that organisms may be increasing $\mathrm{NH}_{4}{ }^{+}$-deprived as plankton biomass increases, which was similar to eutrophic 
lakes (Gardner et al. , 2017).

\subsection{Implications for management}

Our results suggest that $\mathrm{SS}$ is a key factor controlling $\mathrm{NH}_{4}{ }^{+}$recycling rates. High concentrations of SS in the water column of Yangtze River can promote both $\mathrm{NH}_{4}{ }^{+}$regeneration and nitrification rates, resulting in the persistence of algal growth and potential high levels of $\mathrm{NO}_{3}{ }^{-}$concentrations. This is consistent with a previous study which showed that nitrification is one of the major sources of $\mathrm{NO}_{3}{ }^{-}$in the Yangtze River ( $\mathrm{Li}$ et al. , 2010). Thus, effective measures to reduce SS concentrations in this turbid river may reduce the risk of $\mathrm{N}$ pollution. For example, restoration of shoreline vegetation, improvement of land use, and management of soil erosion are recommended to reduce SS concentrations in the lower reaches of Yangtze River.

Most previous studies in Yangtze River pay a special attention to $\mathrm{NO}_{3}{ }^{-}$exports into the East China Sea due to its high concentrations (Zhou et al. , 2008; Mulleret al. , 2008; Liang and Xian, 2018). As a more preferred $\mathrm{N}$ nutrition for most phytoplankton species, $\mathrm{NH}_{4}{ }^{+}$were overlooked in river systems because of low ambient concentrations. Our study and more evidences have shown that $\mathrm{NH}_{4}{ }^{+}$recycling rates can be high even with low ambient concentrations (Jiang et al. , 2019; Gardner et al. , 2017), which can still influence estuaries and its coastal areas profoundly. High $\mathrm{NH}_{4}{ }^{+}$recycling rates and demands reflect rapid microbial metabolism including both algal uptake and bacterial activities, which closely related to the growth and persistence of microbes (Hampel et al. , 2019). Compared to eutrophic lakes, $\mathrm{NH}_{4}{ }^{+}$recycling in the estuary of Yangtze River was influenced in a larger part by bacterial activities. As large amounts of SS and organic matters flow downside into the coastal areas, rapid internal $\mathrm{NH}_{4}{ }^{+}$recycling may also support algal growth and contribute to bloom persistence. Thus, diverse countermeasures should be focused on reducing estuarine inputs of SS or labile organic matters that potentially support high $\mathrm{NH}_{4}{ }^{+}$recycling. Future studies are expected to understand how different properties of SS and organic matter influence water column $\mathrm{NH}_{4}{ }^{+}$ recycling. Results of this study is not only beneficial to the management of this third longest and most economically valuable river in the world, but also valuable to other large rivers and river-estuary continuum systems.

\section{Conclusion}

This study investigated $\mathrm{NH}_{4}{ }^{+}$dynamics including its regeneration, potential uptake, and demand in the river-estuary continuum of Yangtze River. Higher REGs, $\mathrm{U}_{\text {pot }} \mathrm{s}$, and CBAD were found in the estuary, while relatively lower in the river sections. Moreover, compared to in the river sections, the higher regeneration and uptake rates of $\mathrm{NH}_{4}{ }^{+}$as well as CBAD in the estuary are due to higher PN, COD, and SS concentrations. Faster microbial uptake of $\mathrm{NH}_{4}{ }^{+}$than its regeneration result in obvious $\mathrm{NH}_{4}{ }^{+}$demand in the estuary. In addition, $\mathrm{NH}_{4}{ }^{+}$regeneration is an important pathway of $\mathrm{N}$ supply in the Yangtze River, and regenerated $\mathrm{NH}_{4}{ }^{+}$was estimated to be $21.81 \times 10^{8} \mathrm{~kg} \mathrm{~N} \mathrm{yr}^{-1}$, accounting for about $25 \%$ of total $\mathrm{N}$ inputs in the study area. This study indicates that $\mathrm{NH}_{4}{ }^{+}$recycling is critical for regulating the supply and demand of $\mathrm{NH}_{4}{ }^{+}$ along the river-estuary continuum of Yangtze River. Effective managements to reduce SS inputs will alleviate $\mathrm{N}$ pollution and blooms (i.e., red tide) in the river-estuary continuum of the Yangtze River.

\section{Acknowledgments}

This study was financially supported by the National Natural Science Foundation of China (No. 51839011, 41771519, 41671477), Comprehensive evaluation of geological resources and environment in the Yangtze River Economic Belt (DD20190260); the Major Science and Technology Program for Water Pollution Control and Treatment (2017ZX07204005); and The Key Cultivation Project of the Institute's-13th Five-Year Plan (NIGLAS2018GH05), and Science and technology basic work of science and technology (2015FY110900-03). 


\section{CRediT authorship contribution statement}

Jing-Ya Xue: Writing - original draft, Investigation, Conceptualization, Methodology, Data curation. ZhongHua Zhao: Formal analysis, Investigation, Data curation. Xiao-Long Yao: Conceptualization, Investigation. Wei-Ting Liu: Investigation. Lu Zhang: Investigation, Resources, Supervision, Project administration, Funding acquisition.

\section{Conflicts of Interest:}

The authors declare that they have no known competing financial interests or personal relationships that could have appeared to influence the work reported in this paper.

\section{Data Availability Statement:}

The data that support the findings of this study are available from the corresponding author (Professor Lu Zhang, luzhang@niglas.ac.cn).

\section{Appendix A. Supplementary data}

Supplementary data related to this article can be found in supporting information.

\section{Reference:}

Bilotta, G. S. \& Brazier, R. E. (2008). Understanding the influence of suspended solids on water quality and aquatic biota. Water Res42(12): 2849-2861.

Blackburn, T. H. (1979). Method for measuring rates of NH4+ turnover in anoxic marine sediments, using a 15N-NH4+ dilution technique. Applied and Environmental Microbiology 37(4): 760-765.

Bruesewitz, D. A., Gardner, W. S., Mooney, R. F. \& Buskey, E. (2015). Seasonal Water Column $\mathrm{NH}_{4}{ }^{+}$ Cycling Along a Semi-arid Sub-tropical River-Estuary

Continuum: Responses to Episodic Events and Drought Conditions.Ecosystems 18(5): 792-812.

Chen, F., Hou, L., Liu, M., Zheng, Y., Yin, G., Lin, X., Li, X., Zong, H., Deng, F., Gao, J. \& Jiang, X. (2016). Net anthropogenic nitrogen inputs (NANI) into the Yangtze River basin and the relationship with riverine nitrogen export. J GEOPHYS RES-BIOGEO 121(2): 451-465.

Collos, Y., Vaquer, A., Johnston, A. M., Pons, V., Bibent, B. \& Richard, S. (2001). Carbon Fixation, Ammonium Uptake and Regeneration in an Equatorial Lake: Biological Versus Physical Control. Journal of Plankton Research 23(3): 263-270(268).

Connelly, T. L., Baer, S. E., Cooper, J. T., Bronk, D. A., Wawrik, B. \& Wommack, K. E. (2014). Urea Uptake and Carbon Fixation by Marine Pelagic Bacteria and Archaea during the Arctic Summer and Winter Seasons.Applied and Environmental Microbiology 80(19): 6013-6022.

Dai, Z., Du, J., Zhang, X., Su, N. \& Li, J. (2011). Variation of Riverine Material Loads and Environmental Consequences on the Changjiang (Yangtze) Estuary in Recent Decades (1955-2008). Environ. Sci. Technol. 45: 223-227.

Di, Z., Hong, Z. \& Shan, B. (2015). Using sedimentary phosphorus/nitrogen as indicators of shallow lake eutrophication: concentrations or accumulation fluxes. Environmental Earth Sciences 74(5): 3935-3944. 
Diaz, R. J. \& Rosenberg, R. (2008). Spreading dead zones and consequences for marine ecosystems. Science 321(5891): 926-929.

Gardner, W. S., Cavaletto, J. F., Bootsma, H. A., Lavrentyev, P. J. \& Troncone, F. (1998). Nitrogen cycling rates and light effects in tropical Lake Maracaibo, Venezuela. Limnology and Oceanography43: 1814-1825.

Gardner, W. S., Lavrentyev, P. J., Cavaletto, J. F., McCarthy, M. J., Eadie, B. J., Johengen, T. H. \& Cotner, J. B. (2004). Distribution and dynamics of nitrogen and microbial plankton in southern Lake Michigan during spring transition 1999-2000. J Geophys Res 109.

Gardner, W. S., Newell, S. E., McCarthy, M. J., Hoffman, D. K., Lu, K., Lavrentyev, P. J., Hellweger, F. L., Wilhelm, S. W., Liu, Z., Bruesewitz, D. A. \& Paerl, H. W. (2017). Community Biological Ammonium Demand: A Conceptual Model for Cyanobacteria Blooms in Eutrophic Lakes.Environ. Sci. Technol. 51(14): 7785-7793.

Glibert, P. M., Lipschultz, F., J., M. J. \& Altabet, M. A. (1982). Isotope dilution models of uptake and remineralization of ammonium by marine plankton. Limnology and Oceanography 27(4): 639-650.

Gudasz, C., Sobek, S., Bastviken, D., Koehler, B. \& Tranvik, L. J. (2015). Temperature sensitivity of organic carbon mineralization in contrasting lake sediments. J Geophys Res: Biogeosciences 120.

Hampel, J. J., McCarthy, M. J., Gardner, W. S., Zhang, L., Xu, H., Zhu, G. \& Newell, S. E. (2017). Nitrification and ammonium dynamics in Lake Taihu, China: seasonal competition for ammonium between nitrifiers and cyanobacteria. Biogeosciences Discussions : 1-43.

Hampel, J. J., McCarthy, M. J., Neudeck, M., Bullerjahn, G. S., McKay, R. M. L. \& Newell, S. E. (2019). Ammonium recycling supports toxic Planktothrix blooms in Sandusky Bay, Lake Erie: Evidence from stable isotope and metatranscriptome data. Harmful Algae 81: 42-52.

Jiang, X., Zhang, L., Gao, G., Yao, X., Zhao, Z. \& Shen, Q. (2019). High rates of ammonium recycling in northwestern Lake Taihu and adjacent rivers: An important pathway of nutrient supply in a water column.Environ Pollut 252: 1325-1334.

Jiang, Z., Liu, J., Chen, J., Chen, Q., Yan, X., Xuan, J. \& Zeng, J. (2014). Responses of summer phytoplankton community to drastic environmental changes in the Changjiang (Yangtze River) estuary during the past 50 years. Water Res 54: 1-11.

Jin, X. \& Tu, Q. (1990). The Stand Methods for Observation and Analysis in Lake Eutrophication. Beijing: Chinese Environmental Science Press.

Li, S., Liu, C., Li, J., Liu, X., Chetelat, B., Wang, B. \& Wang, F. (2010). Assessment of the Sources of Nitrate in the Changjiang River, China Using a Nitrogen and Oxygen Isotopic Approach. Environ. Sci. Technol. 44: 1573-1578.

Liang, C. \& Xian, W. (2018). Changjiang nutrient distribution and transportation and their impacts on the estuary. Cont Shelf Res165: 137-145.

Lin, X., Hou, L., Liu, M., Li, X., Yin, G., Zheng, Y. \& Deng, F. (2016). Gross Nitrogen Mineralization in Surface Sediments of the Yangtze Estuary. PLoS One 11(3): e0151930.

Liu, T., Xia, X., Liu, S., Mou, X. \& Qiu, Y. (2013). Acceleration of denitrification in turbid rivers due to denitrification occurring on suspended sediment in oxic waters. Environ. Sci. Technol. 47(9): 4053-4061.

Liu, X., Beusen, A. H. W., Van Beek, L. P. H., Mogollon, J. M., Ran, X. \& Bouwman, A. F. (2018). Exploring spatiotemporal changes of the Yangtze River (Changjiang) nitrogen and phosphorus sources, retention and export to the East China Sea and Yellow Sea. Water Res 142: 246-255.

Mccarthy, M. J., Lavrentyev Peter, J., Yang, L., Zhang, L., Chen, Y., Qin, B., Gardner \& Wayne, S. (2007a). Nitrogen dynamics and microbial food web structure during a summer cyanobacterial bloom in a subtropical, 
shallow, well-mixed, eutrophic lake (Lake Taihu, China).Hydrobiologia 581(1): 195-207.

Mccarthy, M. J., S., G. W., J., L. P., M., M. K., J., J. F. \& M., K. D. (2007b). Effects of Hydrological Flow Regime on Sediment-water Interface and Water Column Nitrogen Dynamics in a Great Lakes Coastal Wetland (Old Woman Creek, Lake Erie). Journal of Great Lakes Research 33(1): 219-231.

Muller, B., Berg, M., Yao, Z. P., Zhang, X. F., Wang, D. \& Pfluger, A. (2008). How polluted is the Yangtze river? Water quality downstream from the Three Gorges Dam. Sci Total Environ 402(2-3): 232-247.

Mulvenna, P. F. \& Graham, S. (1992). A modified manual method for the determination of Urea in seawater using diacetylmonoxime reagent.Estuar Coast Shelf S 34: 429-438.

Odman, F., Ruth, T. \& Ponter, C. (1999). Validation of a field filtration technique for characterization of suspended particulate matter from freshwater. Part I. Major elements. Applied Geochemisrty 14: 301-317.

Paerl, H. W., Xu, H., McCarthy, M. J., Zhu, G., Qin, B., Li, Y. \& Gardner, W. S. (2011). Controlling harmful cyanobacterial blooms in a hyper-eutrophic lake (Lake Taihu, China): the need for a dual nutrient (N \& P) management strategy. Water Res 45(5): 1973-1983.

Qin, B., Zhu, G., Gao, G., Zhang, Y., Li, W., Paerl, H. W. \& Carmichael, W. W. (2010). A drinking water crisis in Lake Taihu, China: linkage to climatic variability and lake management. Environ Manage 45(1): 105-112.

Sipler, R. E., Baer, S. E., Connelly, T. L., Frischer, M. E., Roberts, Q. N., Yager, P. L. \& Bronk, D. A. (2017). Chemical and photophysiological impact of terrestrially-derived dissolved organic matter on nitrate uptake in the coastal western Arctic. Limnology and Oceanography 62(5): 1881-1894.

Tang, D., Di, B., Wei, G., Ni, I. H., Oh, I. S. \& Wang, S. (2006). Spatial, seasonal and species variations of harmful algal blooms in the South Yellow Sea and East China Sea. Hydrobiologia 568(1): 245-253.

Turner, A. \& Millward, G. E. (2002). Suspended Particles: Their Role in Estuarine Biogeochemical Cycles. Estuarine, Coastal and Shelf Science 55(6): 857-883.

Wang, H., Yang, Z., Wang, Y., Saito, Y. \& Liu, J. P. (2008). Reconstruction of sediment flux from the Changjiang (Yangtze River) to the sea since the 1860s. Journal of Hydrology 349(3-4): 318-332.

Wong, G. T. F., Gong, G.-C., Liu, K.-K. \& Pai, S.-C. (1998). "Excess nitrate" in the East China Sea. Estuarine, Coastal and Shelf Science 46: 411-418.

Wu, Z., Liu, Y., Liang, Z., Wu, S. \& Guo, H. (2017). Internal cycling, not external loading, decides the nutrient limitation in eutrophic lake: A dynamic model with temporal Bayesian hierarchical inference. Water Res 116: 231-240.

Xia, X., Liu, T., Yang, Z., Zhang, X. \& Yu, Z. (2013). Dissolved organic nitrogen transformation in river water: Effects of suspended sediment and organic nitrogen concentration. Journal of Hydrology484: 96-104.

Xia, X., Yang, Z. \& Zhang, X. (2009). Effect of Suspended-Sediment Concentration on Nitrification in River Water: Importance of Suspended Sediment-Water Interface. Environ. Sci. Technol. 43: 3681-3687.

Xue, J., Liu, W., Jiang, X., Zhao, Z., Zhang, L., Cai, Y. \& Wang, X. (2019). Ammonium recycling and its influencing factors along the littoral zone of the middle reaches of Yangtze River. Resources and Environment in the Yangtze Basin 28(11): 2735-2742.

Yan, W., Mayorga, E., Li, X., Seitzinger, S. P. \& Bouwman, A. F. (2010). Increasing anthropogenic nitrogen inputs and riverine DIN exports from the Changjiang River basin under changing human pressures. Global Biogeochemical Cycles 24: 1-14.

Yang, S. L., Zhang, J. \& Xu, X. J. (2007). Influence of the Three Gorges Dam on downstream delivery of sediment and its environmental implications, Yangtze River. Geophys Res Lett 34. 
Yao, X., Zhang, L., Zhang, Y., Xu, H. \& Jiang, X. (2016). Denitrification occurring on suspended sediment in a large, shallow, subtropical lake (Poyang Lake, China). Environ Pollut 219: 501-511.

Yi, Y., Yang, Z. \& Zhang, S. (2011). Ecological risk assessment of heavy metals in sediment and human health risk assessment of heavy metals in fishes in the middle and lower reaches of the Yangtze River basin. Environmental Pollution 159(10): 2575-2585.

Yin, G., Hou, L., Liu, M., Liu, Z. \& Gardner, W. S. (2014). A novel membrane inlet mass spectrometer method to measure ${ }^{15} \mathrm{NH}_{4}{ }^{+}$for isotope-enrichment experiments in aquatic ecosystems. Environmental Science and Technology 48(16): 9555-9562.

Zhang, W., Gu, J., Li, Y., Lin, L., Wang, P., Wang, C., Qian, B., Wang, H., Niu, L., Wang, L., Zhang, H., Gao, Y., Zhu, M. \& Fang, S. (2019). New Insights into Sediment Transport in Interconnected River-Lake Systems Through Tracing Microorganisms. Environ. Sci. Technol.53(8): 4099-4108.

Zheng, Z.-Z., Wan, X., Xu, M. N., Hsiao, S. S.-Y., Zhang, Y., Zheng, L.-W., Wu, Y., Zou, W. \& Kao, S.-J. (2017). Effects of temperature and particles on nitrification in a eutrophic coastal bay in southern China. $J$ Geophys Res: Biogeosciences 122(9): 2325-2337.

Zhou, M., Shen, Z. \& Yu, R. (2008). Responses of a coastal phytoplankton community to increased nutrient input from the Changjiang (Yangtze) River. Continental Shelf Research 28: 1483-1489.

Zhou, Y., Xu, X., Han, R., Li, L., Feng, Y., Yeerken, S., Song, K. \& Wang, Q. (2019). Suspended particles potentially enhance nitrous oxide $(\mathrm{N} 2 \mathrm{O})$ emissions in the oxic estuarine waters of eutrophic lakes: Field and experimental evidence. Environ Pollut 252(Pt B): 1225-1234.

\section{Hosted file}

Tables.pdf available at https://authorea.com/users/403505/articles/514920-suspended-solidsinduced-increasing-microbial-ammonium-recycling-along-the-river-estuary-continuum-ofyangtze-river

\section{Hosted file}

Figures.pdf available at https://authorea.com/users/403505/articles/514920-suspended-solidsinduced-increasing-microbial-ammonium-recycling-along-the-river-estuary-continuum-ofyangtze-river 